\title{
Improving Strategic Management of the Business Entities
}

\author{
Anvar V. Gumerov ${ }^{1}$, Regina R. Kharisova ${ }^{2}$, Adeliya V. Pavlova ${ }^{3}$, Irina Y. Litvin ${ }^{4}$, Karina R. Nabiullina ${ }^{2}$, Neile K. \\ Schepkina $^{5} \&$ Ilshat T. Sabirov ${ }^{6}$ \\ ${ }^{1}$ Kazan National Research Technical University named after A. N. Tupolev, Kazan, Russia \\ ${ }^{2}$ Kazan State University of Architecture and Engineering, Kazan, Russia \\ ${ }^{3}$ Kazan Federal University, Kazan, Russia \\ ${ }^{4}$ Moscow State University of Mechanical Engineering, Moscow, Russia \\ ${ }^{5}$ Amur State University, Blagoveschensk, Russia \\ ${ }^{6}$ Yelabuga Institute of Kazan Federal University, Yelabuga, Russia \\ Correspondence: Anvar V. Gumerov, Kazan National Research Technical University named after A. N. Tupolev, \\ K. Marks Street 10, Kazan, Tatarstan, 420111, Russia. E-mail: solo73@inbox.ru
}

Received: October 24, 2014 Accepted: December 3, 2014 Online Published: December 18, 2014

doi:10.5539/res.v7n1p23 URL: http://dx.doi.org/10.5539/res.v7n1p23

\begin{abstract}
The purpose of this article is aimed at improving the conditions for the development of the business entities strategic management in respect to the agency conflicts. The submitted article specifies a method to protect the principal's interests in decision-making under current management. The basis of the submitted work serves the application of the quality management tools in the system of strategic management, as it allows to keep a long-term orientation and considers the formation of the customer value as the basic object of management that conforms the management paradigm from the point of the principal. The article presents possible scenarios of large business entities development using the methods and mechanisms of the strategic management of a business entity with the use of the quality management tools. This article is intended for managers, executives, researchers engaged in strategic planning and development of the enterprise structures.
\end{abstract}

Keywords: strategic planning, business entities, quality management tools, agency conflict, scenario development

\section{Introduction}

\subsection{Background}

The postindustrial socialization that is characterized by computerization of the economic space, intensifying globalization processes and intensifying turbulence of the market environment requires the new management tools aimed at increasing the producers' and their products competitiveness. In this regard, it seems rational to appeal to the quality management (Ishikawa, 1988; Crosby, 2004; Deming, 2011) tools the effectiveness of which is confirmed by the national and foreign practices of doing business activities in terms of acquiring long-term competitive advantages by business entities.

The analysis of the management systems within national companies shows that, despite the growing interest in quality management methods from particular business entities, the business community shows lack of necessary knowledge and experience in the development and implementation of the effective development strategy, which is based on the use of quality management tools that provide control over the external environmental factors. This is caused by the noncompliance of the general and strategic management principles with the provisions of quality management in general and the modern concept of total quality management (Gugelev, 2007; Gorbashko, 2008; Glischev, 2009), which addresses the issues of improving the production management efficiency, employees motivation, increase in the quality products production based on the implementation of the process approach, internal audit of the management system, remedial and preventive actions .

\subsection{Status of a Problem}

This research is based on the works of leading foreign and national economists. The entrepreneurship as a production factor is discussed in the works of Russian (Vikhanskiy, 2004; Gorfinkel, 2002; Yashin, 1994, etc.) 
and foreign (Drucker, 2008; Thompson \& Formby, 1998; Schumpeter, 2007, etc.) authors.

The conceptual baseline of total quality management and its introduction into the work of industrial enterprises is investigated in the writings of (Deming, 2011; Isikava, 1988; Krosbi, 2004, etc.).

The content and the methods of the strategy development of the business entities is discussed in the works of (Drucker, 2008; Mintzberg, 2001; Thompson \& Striklend, 2006; Webster, 2010, etc.).

The research has shown that the strategic management of traditional business entities is in the focus of scholars' and practitioners' attention owing to the increasing competition and high level of the external volatility of business entities. However, the analysis of the alternative issues in terms of the company's development strategy content shows that the theoretical and methodological foundations of the quality management inclusive of the strategic management principles and significant changes in the entrepreneurship content as a production factor in the post-industrial society has not been thoroughly investigated. The objectives of the large industrial associations are the stabilization and business solvency growth while determining the mechanisms of the strategy development and the arrangements of the entities' effective interaction

\subsection{Problem of Investigating}

The concurrence of the common and strategic management principles will provide solutions connected with the increasing efficiency of the production management, employees motivation, increasing quality overall production, serving stakeholders' interest at most. In this regard it seems appropriate to apply to the quality management tools which efficiency has already been confirmed by domestic and foreign practices. The submitted research is determined by the necessity to form a development strategy adapted to the conditions of uncertain external environment of a business entity, ensuring the implementation of conflicting interests of the owners (entrepreneurs) and managers including the society and state interests, the necessity in the Russian and foreign experience in applying quality management tools in connection with the principles of strategic management.

\section{Experimental}

\subsection{The Objectives of the Research}

Carry out development of possible scenarios of large business entities development using the methods and mechanisms of the strategic management of a business entity with the use of the quality management tools.

\subsection{Theoretical and Empirical Methods}

The prime postulate is rendering entrepreneurship as a factor of production providing an alternative between classical, neoclassical and relational contracts for the effective allocation of assets and achievement of institutional balance. Meanwhile the business entities are treated as the members of contractual relations and at the same time the subjects of the transactions institutional design. An attributable feature of business becomes its ability to develop and implement institutional projects focused on the development of the society and to ensure the achievement of institutional balance (either effective or ineffective depending on the dynamics of the transaction expenses).

While forecasting the purposes of business entity performance in terms of quality, it is necessary to take into account both the development trends established in the process of the organization functioning in retrospect and the possibilities of rapid development of the business entity as a result of the strategic management processes including the probability of their implementation owing to the principal's priorities. For the last reason it is advisable to take an approach based on the elements of games theory, which can be formalized as follows:

$C r_{l}=C r_{0} k_{e x} k_{i t}$, where $\mathrm{Cr}_{1,0}$ - the value of the test parameter respectively in the forecast and the current period;

$\mathrm{k}_{\mathrm{ex}}$ - extrapolation factor that characterizes the ultimate trend of the test parameter change;

$\mathrm{k}_{\mathrm{it}}$ - the iteration factor accounting for the potential test parameter changes, defined as follows:

$k_{i t}=1+\left(p\left(f\left(x_{i}\right)_{0}+\Sigma_{j} x_{j}\right)-c x_{j}\right)$

where $\mathrm{p}$ - the probability of making a decision supporting the principal's interests by the employed management, defined in terms of the agency conflicts significance, ranging from 0 to 1 ;

$\mathrm{f}\left(\mathrm{x}_{\mathrm{i}}\right)_{0}$ - the integral influence of the test parameter defining the strategic development process of a business entity that arises as a result in the current period, rub.;

$\Sigma_{\mathrm{j}} \mathrm{x}_{\mathrm{j}}$ - the sum of the stimulus of the parameters changeable in the forecast period over the test parameter, rub;

$\mathrm{cx}_{\mathrm{j}}-$ the expenses of a business structure to form the sum of the stimulus of the changeable in the forecast period 
parameters over the test parameter, rub.

\subsection{The Basis of the Research}

The basis of the research has become the organizations: JSC "KAMAZ", JSC "Nizhnekamskneftekhim», JSC "Tatneft”, JSC "Kazan Helicopter Plant” (KHP).

\section{Results}

\subsection{Defining the Position of the Strategic Development of the Company}

The analysis of business relations development allowed to clarify the I. Schumpeter's (Schumpeter,2007) trajectory model of the functional structure of a business process, comprising the stage of individual entrepreneurship, the stage of recruiting the staff and the stage of transmitting the functions of resource allocation in terms of formation at the third stage of development in the framework of the "principal-agent" model the contradictions between the interests of the contract parties concerning the products and processes quality. Under the terms of neo-institutional approach, the extension of the social division of labor leads to the contradiction between the assets amount, the property rights of which belong to the business entities (principals) and qualitative restrictions (the ability of their efficient allocation). The resolution of this conflict implies the necessity to contract an agency agreement as an incomplete contract, in which a part of proprietary rights is transferred by the principal to the agent. However, if the agent is focused on improving the quality of the products and processes and becomes the initiator of the innovation cycle, then the principal tends to continue such a contract, which in the long run can essentially vary and take the form of a share in the ownership.

Thus, the discordant positions of the agency agreement participants constituting the essence of the corporations in terms of quality cause differences in the development strategy of business structures, which may be focused primarily on the implementation of the principals' (owners), the agents' (managers) interests or provide congruence of the targets of their choice.

Therefore, the regulatory (evaluation) component in the essence of the products and processes quality specifies the difference in determining its performance system and its role in the development of particular business entities and national economy on the whole from the perspective of the business community represented by the owners and managers.

\subsection{Algorithm of Management from the Viewpoint of the Principal}

In order to resolve the agency conflict arising from the strategic management of a business entity and protect the principal's interests in decision-making under current management it is necessary to ensure the application of the quality management tools, as these tools allow to stick to a long-term orientation and regard the formation of consumer values as the primary object of management, which corresponds to the management paradigm from the point of the principal. The procedure for the this approach implementation is as follows.

1) The formation of the mission of a business entity. The entrepreneur should clearly realize the key goals of the enterprise creation and formulate its strategic vision that will ensure keeping these values in focus of the hired management while implementing the operational management processes.

2) The development of the quality policy. In terms of this stage the strategic objectives of the business structure corresponding to its mission are formulated, a platform for creating complex evaluation indicators to realize the mission of the business structure are formulated. Significantly, as the purpose of this document in terms of agency conflict resolution is to provide the value-based management for the employees, laying down the policy in the area of quality involves the use of non-quantitative aspects of improvement on account of the initial quantitative orientation of the hired management.

3) Setting quality objectives. While setting the quality goals it is necessary to maintain their value orientation in order to resolve the agency conflict, whereupon the ratio of material and non-material indicators describing the business entities goals in terms of quality is recommended at the level of 80/20 to 70/30.

4) Bringing the mission, policy and quality objectives to the staff. Implementation of this stage should be carried out within the proven quality management procedure; the owners of the business entity should participate in this process thus ensuring their interests and priorities in economic activity as well as providing deep understanding of the set goals in terms of quality by the employees.

The realization of this algorithm will form an accurate control system over the stated mission implementing, policy and quality objectives; at the same time to ensure the accuracy of the implementation of strategic management processes at all stages it is advisable to use X-maps and R-maps to assess the performance of the goals set at the third stage of the foregoing algorithm and arrange an appropriate adjustment process if these 
instruments identify a system error.

\subsection{Development Scenarios for the Development of Large Industrial Enterprises}

Introduction of the considered industrial enterprises ideology "total quality" (Juran, 1992; Okrepilov, 2000; Lapidus, 2002; Blagodarov, 2009), where the quality improvement becomes the key parameter, but not in relation to the quality management but to strategic organizational development that provides the projection over the consequences of any activity influencing the company thus allowing to focus on common long -term goals achievement. The practical realization of the quality management methods implementation into the strategic planning in corporations, allows you to set setting series of restrictions and possible extreme points which are crucial for the development strategy.

Forecasting the results of the application of the proposed methods and the mechanisms of the strategic management of a business entity using tools of quality management has been performed within the following scenarios:

- a basic scenario intended to maintain the existing trends in the enterprise development;

- a negative scenario implying the intensification of the agency conflicts caused by the absence of the submitted methods to reduce its impact;

- an optimistic scenario implying a decrease in the agency conflicts impact as a result of the submitted methods and mechanisms of the business entities strategic management on the basis of the quality management methods.

The forecast has been conducted a t the premises of five large enterprises of the Republic of Tatarstan the development of which is significantly influenced by the agency conflict. The example of a forecast in terms of the return on equity is presented through the large industrial enterprises (corporations) of JSC "KAMAZ" and JSC “Nizhnekamskneftekhim” (Fig. 1), JSC “Tatneft” and JSC “Kazan Helicopter Plant” (KHP) (Fig. 1).

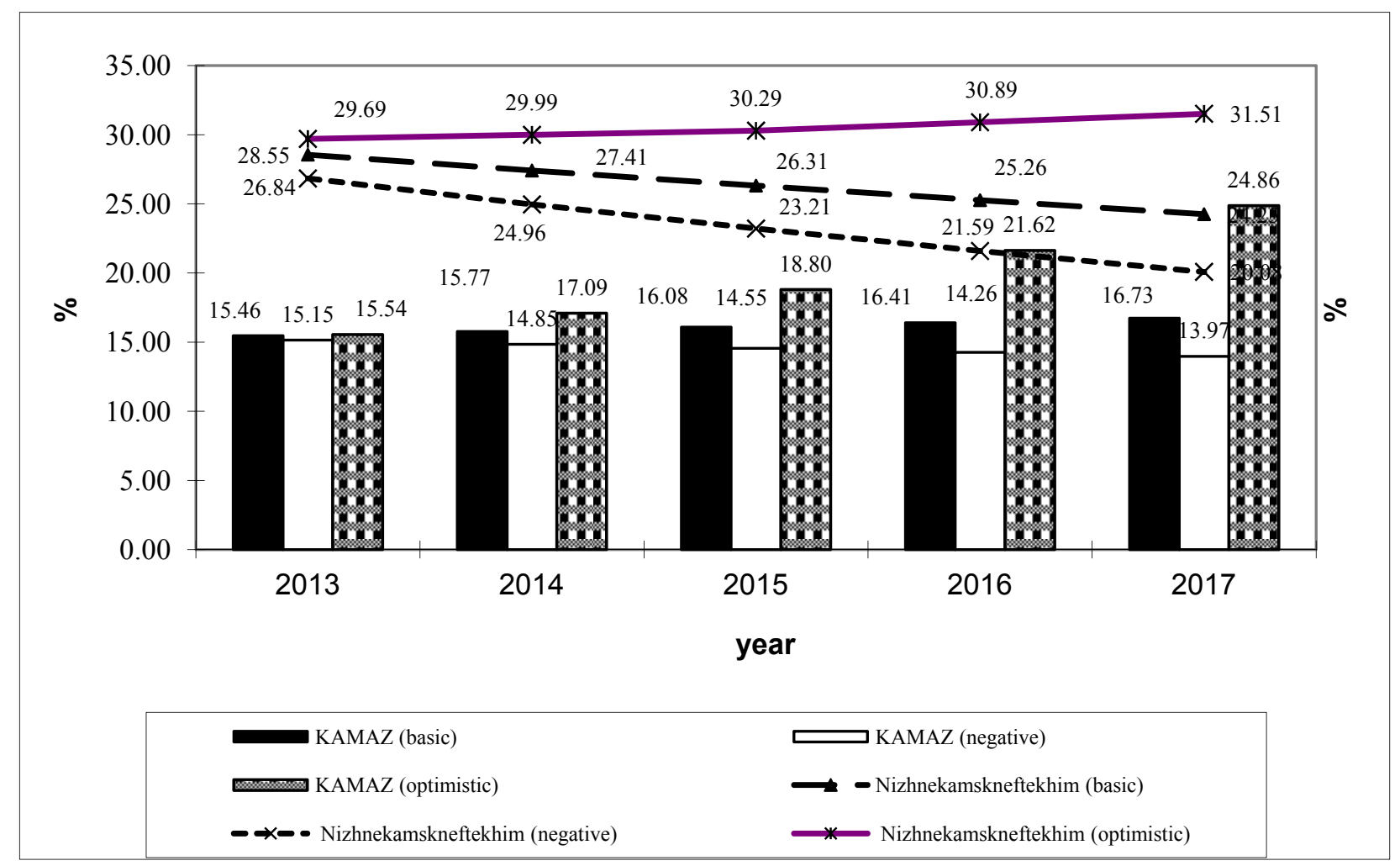

Figure 1. The return on equity of JSC "KAMAZ" and JSC "Nizhnekamskneftekhim" in scenarios for 2013-2017 


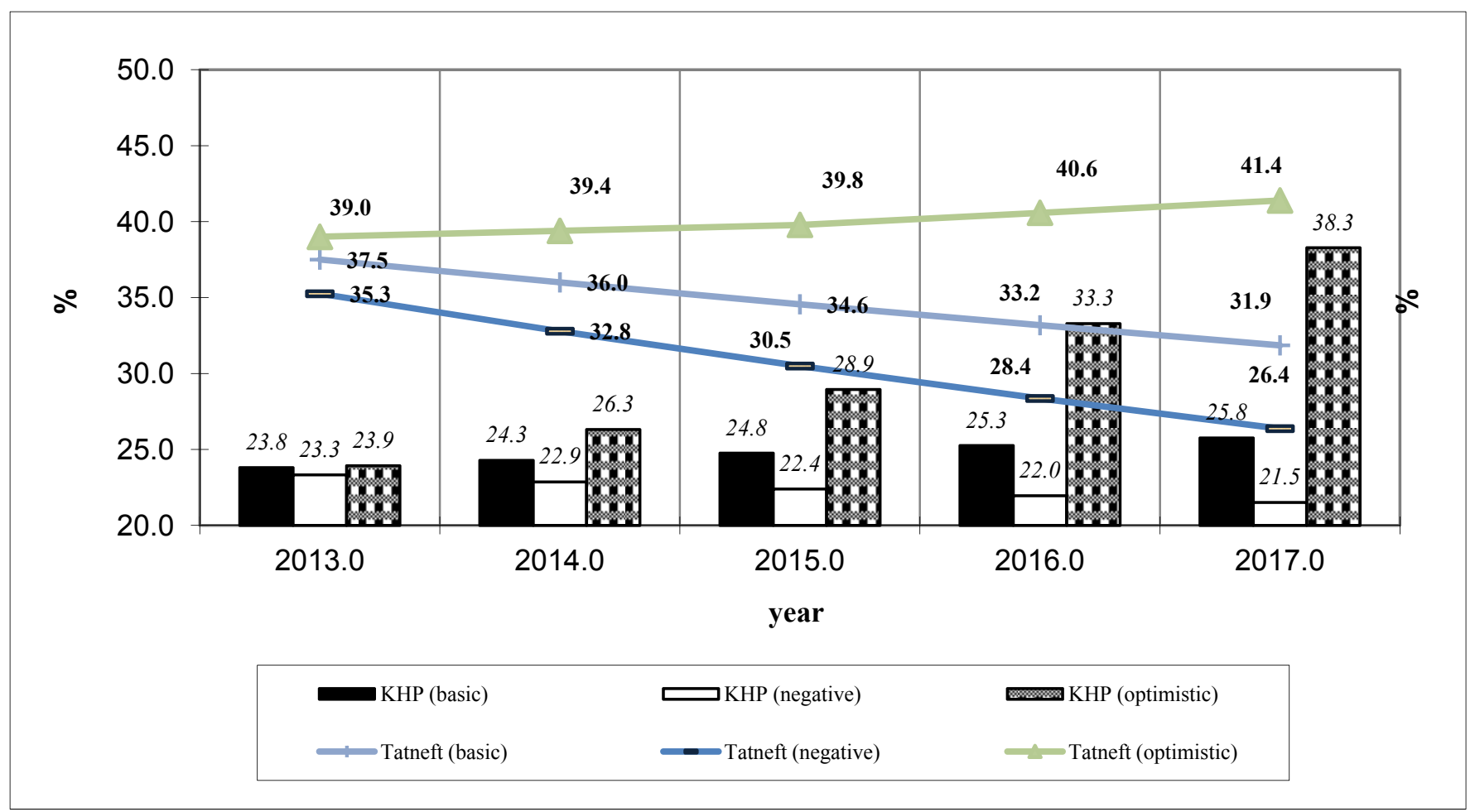

Figure 2. The return on equity of JSC "Tatneft" and JSC "Kazan Helicopter Plant" (KHP) in scenarios for 2013-2017

The results analogous to those shown in Fig. 1, Fig. 2, were received when forecasting the risk growth rates, working efficiency and customer value growth that confirms the economic expediency of the submitted mechanisms of the business entities strategic management on the basis of the quality management tools. In the process of strategic management of business entities on the basis of the quality management tools a scenario planning can reduce the negative impact of the environmental factors through their predestination.

\section{Discussions}

Therefore, the integration of the quality management tools into strategic management of the business entities in real sector of economy including the agency conflicts and agency expenses provides positive dynamics of the corporate financial and economic performance, contributes to the competitiveness in the national and foreign market. The research has formulated the strategies of business entities development in accordance with the organization lifecycle, a form of agency conflict manifestation, the degree of control over the turbulent environmental factors. The most important particularity of the Total Quality Management theory is that strategic quality planning of all the processes is carried out inseparably from general strategy plans - the performance aimed at steady market position which can be achieved with a due regard to strategic focusing on the quality of the end product and the management system on the whole.

\section{Conclusion}

The solution of the problems presupposes transition to the totally new management level that is characterized by the strategic mode of solutions, validity, consistency and performance efficiency. The authors submit a methodical approach to forecasting the quality achievements by the business entities, where the implementation of the agency conflict is a significant part of the strategic management system. The performed simulation confirms the economic expediency of the submitted mechanisms of business entities strategic management on the basis of the quality management tools.

\section{References}

Blagodarov, K. V. (2009). The role of strategic planning in the development of machine-building enterprise. Journal of Economics and Management, 10, 124-127.

Crosby, F. (2004). Quality and I. Life business in America (p. 264). Moscow Standards and Quality publishing. 
Deming, E. (2011). Out of the crisis: A new paradigm of people management systems and processes (p. 419). Moscow Alpina Publisher.

Drucker, P. (2008). Effective management of the enterprise (p. 400). Moscow Vilyams Publisher.

Garfinkel, V. Y. et al. (2002). Entrepreneurial type of management (p. 124). Moscow Economic literature Publisher.

Glischev, A. V. (2009). Quality, efficiency, morality (p. 358). Moscow publishing Premium Engineering.

Gorbashko, E. A. (2008). Quality Management (p. 384). St. Petersburg, Piter Publisher.

Gugelev, A. V. (2007). Standardization, metrology and certification (p. 210). Moscow Higher Education publishing.

Ishikawa, K. (1988). Japanese quality management. Moscow Economics publishing.

Juran, J. M. (1992). Strategic Quality Management (p. 346). NY McGra-Hill Inc.

Lapidus, V. A. (2002). Universal quality (TQM) in Russian companies (p. 431). Moscow News" publishing.

Mintzberg, G. et al. (2001). Strategic process (p. 567). St. Petersburg, Piter Publisher.

Okrepilov, V. V. (2000). Quality management (p. 912). St. Petersburg Nauka publishing.

Schumpeter, J. A. (2007). Theory of Economic Development (p. 400). Moscow Direct Media Year Publisher.

Thompson, A., \& Formby, J. (1998). Economics of the firm (p. 544). Moscow BINOM Publisher.

Thompson, A. A., \& Striklend, A. (2006). Strategic management, Concepts and situation for analysis (p. 928). Moscow Williams Publisher.

Vikhansky, O. S. (2004). The strategic management (p. 296). Moscow Economist Publisher.

Webster F. (2010). Pricing Strategy. Journal of Marketing and market research, 1, 21-37.

Yashin, N. S. (1994). Competitiveness of industrial enterprises: Methodology, evaluation, regulation (p. 248). Saratov: SGEA Centre.

\section{Copyrights}

Copyright for this article is retained by the author(s), with first publication rights granted to the journal. This is an open-access article distributed under the terms and conditions of the Creative Commons Attribution license (http://creativecommons.org/licenses/by/3.0/). 